DEPARTMENT OF THE INTERIOR

U.S. GEOLOGICAL SURVEY

\title{
LANDSLIDE AND DEBRIS-FLOW HAZARDS \\ CAUSED BY THE JUNE 27, 1995, STORM \\ IN MADISON COUNTY, VIRGINIA \\ (INCLUDES DISCUSSION OF MITIGATION OPTIONS)
}

BY

WIECZOREK, G.F. ${ }^{1}$, GORI, P.L. ${ }^{1}$, CAMPBELL, R.H. ${ }^{1}$, AND MORGAN, B.A. ${ }^{1}$

OPEN-FILE REPORT 95-822

This report is preliminary and has not been reviewed for conformity with U.S. Geological Survey editorial standards (or with the North American Stratigraphic Code). Any use of trade, product, or firm names if for descriptive purposes only and does not imply endorsement by the U.S. Government.

${ }^{1}$ USGS, 922 National Center, Reston, VA 22092

RESTON, VIRGINIA

October, 1995 


\section{TABLE OF CONTENTS}

$\begin{array}{ll}\text { ABSTRACT } & 1\end{array}$

$\begin{array}{ll}\text { INTRODUCTION } & 1\end{array}$

DEBRIS FLOWS 2

$\begin{array}{ll}\text { HAZARD IDENTIFICATION } & 3\end{array}$

HAZARD MITIGATION

$\begin{array}{ll}\text { RECOMMENDATIONS } & 7\end{array}$

$\begin{array}{lr}\text { REFERENCES } & 8\end{array}$

$\begin{array}{ll}\text { GLOSSARY } & 13\end{array}$

FIGURES 


\title{
LANDSLIDE AND DEBRIS-FLOW HAZARDS CAUSED BY JUNE 27, 1995, STORM IN MADISON COUNTY, VIRGINIA (INCLUDES DISCUSSION OF MITIGATION OPTIONS)
}

\author{
ABSTRACT \\ A severe rainstorm on June 27, 1995, triggered hundreds of landslides from the steep \\ hillsides of Madison County, Virginia. Most of these landslides transformed into debris flows that \\ inundated the areas below causing damage to everything in their path and added large amounts of \\ sediment to downstream flooding. The first in a series of open-file reports describes the general \\ damage caused by this storm, the process by which debris flows are initiated, and the general \\ methods that are used worldwide to identify and mitigate areas subject to debris-flow hazards. \\ This first report also includes several general options for mitigating debris-flow hazards in \\ Madison County. Subsequent open-file reports include more documentation of the storm's \\ effects, more detailed identification of areas susceptible to debris flows, and specific \\ recommendations for mitigating debris-flow hazards in Madison County.
}

\section{INTRODUCTION}

During late June of 1995 , a series of severe thunderstorms with heavy rain caused landslides ${ }^{1}$, debris flows, and flooding in the Blue Ridge Mountains of Virginia. Early estimates were that 1700-2000 houses were heavily damaged or destroyed, 35,000 acres of crops were destroyed, 8 people died ( 7 by drowning and 1 from debris flows), and property damage amounted to at least $\$ 112$ million. State and federal disaster declarations were made in response to this damage.

The area in Madison County (fig. 1) containing the headwaters of the Conway, Rapidan, and Robinson Rivers was one of the most severely impacted. Intense rainfall on June 27 triggered hundreds of landslides, most commonly soil slides (soil slips) that transformed into debris flows as they traveled rapidly down steep hillsides (figs. $2,3,4$ ). The debris flows entered steep channels, incorporating much additional material within their slurries before emerging from canyons and depositing large quantities of rocky debris onto alluvial fans (figs. 5, 6). Some debris flows also contributed large amounts of sediment to streams and rivers. Sediment-laden floodwater overtopped river banks in many places (fig. 7) and spread widely over the flood plain.

Debris-flow hazards have not been widely recognized by the public in the Blue Ridge

\footnotetext{
'In this report, "landslide" is used as a general term for various slope-movement processes, including debris flow. The principal classes of landslides caused by the storm were slides and flows, these terms were defined by varnes (1978). In almost all documented cases, debris flows caused by the storm began as shallow slides, so movement involved both sliding and flow. The term "soil slide-debris flow" or simply "debris flow" is used for this complex movement. For definitions of these or other technical terms refer to the glossary at the end of this report.
} 
Mountains. Clark (1987) documented 51 historical debris-flow events between 1844 and 1985 in the Appalachians south of the glacial border; this is probably significantly lower than the actual number because such events are seldom well documented historically. In 1969, Hurricane Camille triggered abundant debris flows in the Blue Ridge Mountains of Nelson County, Virginia (fig. 1), approximately 90 miles south of Madison County. Hurricane Camille was responsible for 150 deaths, in rural Nelson County it destroyed more than 100 bridges, and caused more than $\$ 100$ million of property damage (Williams and Guy, 1973). These casualties and damage were largely a consequence of rapidly moving debris flows during the peak of the rainfall between midnight and 4 a.m. (Kochel, 1987). A storm in November, 1985, produced record floods and extensive landslides and debris flows in the Potomac and Cheat River basins in West Virginia and Virginia; this storm was responsible for 70 deaths and $\$ 1.3$ billion in damages to homes, businesses, roads, and farmlands (Jacobson, 1993).

Whereas some landslides move slowly and cause damage gradually, debris flows can move so rapidly that they destroy property and take lives suddenly and unexpectedly. They commonly start on steep hillslopes as shallow soil slides that liquefy, accelerate to speeds of 35 miles per hour or more, and flow down hillslopes and channels until slowing on more gentle ground. These catastrophic flows can destroy homes, wash out roads and bridges, sweep away cars, knock down trees, and obstruct streams and roadways with thick deposits of mud, rocks and vegetation.

This report describes when, where, and why debris flows occur and what can be done to limit the damage they cause. Worldwide examples illustrate a wide range of hazard-mitigation techniques that might be considered for application in the Blue Ridge Mountains.

\section{DEBRIS FLOWS}

Fast-moving flows of mud and rock, called debris flows, are among the most destructive types of landslides and are responsible for substantial damage and loss of life worldwide. They are viscous slurry flows containing more sediment than normal floods and more water than many other types of landslides (Pierson and Costa, 1987). Their consistency ranges from watery mud to stiff, rocky mud similar to wet concrete and dense enough to carry boulders, trees, and cars.

Debris flows are triggered predominantly by adding moisture to soil on steep slopes faster than the moisture can drain away leading to a temporary condition of perched water in the soil. Typically, the water is added by either intense rainfall or rapid snowmelt. Monitoring of rainfall and correlation with times of debris flows has led to recognition of rainfall thresholds and improved the capability of real-time evaluation and warning of debris-flow hazards. Although the amount of soil moisture antecedent to a storm is important, the duration of high-intensity rainfall during a storm has been recognized as the most significant factor in triggering debris flows. Large numbers of heavily damaging debris flows caused by periods of high-intensity rainfall occurred in the Los Angeles, California, area during the winters of 1915-16, 1933-34, 1937-38, 1951-52, 1961-62, 1968-69, 1977-78, and 1979-80 (Weber and others, 1979; Weber, 1980). The relationship of rainfall intensity to debris-flow occurrence in the Los Angeles area is demonstrated 
by the heavy rainstorm of 18-26 January 1969 which caused extensive debris-flow activity. During that period almost all the debris flows occurred where (1) total seasonal antecedent rainfall exceeded 10 inches and (2) the rainfall intensity exceeded 0.25 inches per hour (Campbell, 1975). The requirements of antecedent rainfall and high-intensity rainfall apply to most areas where debris flows have been studied, but specific amounts vary regionally depending largely on soil thickness, permeability of soil and bedrock, and topography. Measurements of the intensity and duration of rainfall have been used as the basis for empirical thresholds for the triggering of debris flows in northern California (Cannon and Ellen, 1985), in North Carolina (Neary and Swift, 1987), in Puerto Rico (Jibson, 1989), and in Hawaii (Wilson and others, 1992). Recognition of rainfall thresholds has improved the capability of real-time evaluation and warning of debris-flow hazards (Keefer and others, 1987).

Debris flows commonly originate in soils within swales or topographic depressions, referred to as "hollows" in some parts of the Appalachians. Infiltrating rainfall can saturate these soils and create temporarily perched water tables over less permeable bedrock (fig. 8). Depending on the soil properties, the thickness of the soil, and the rate of infiltrating rainfall, shallow landslides may be initiated that quickly transform into debris flows. Debris flows initiating in the steep upper parts of watersheds can be funneled into channels, where they continue travelling long distances to canyon mouths and beyond, depositing on fans or being diluted and proceeding as heavily sediment-laden debris floods (fig. 9). Where debris flows from different source areas combine in canyons, their destructive power can greatly increase. During the early 1980's, debris flows travelled beyond the mouths of several canyons along the Wasatch Front, north of Salt Lake City, Utah, causing substantial damage in local communities (Wieczorek and others, 1989).

\section{HAZARD IDENTIFICATION}

Areas subject to debris-flow hazards can be identified through geological studies. Previous investigations in many parts of the United States have shown that source areas of debris flows are typically steep hillsides ranging from 18 to 45 degrees in steepness (Campbell, 1975; Clark, 1987; and Ellen, 1988). For example, in the foothills of the Blue Ridge in Tennessee, Koch (1974) found source areas ranging from 32 to 43 degrees in steepness, with an average value of 38 degrees. This wide range of slope steepness reflects a large natural variation in thickness of soil, as well as other geologic, hydrologic, and topographic characteristics. In studies of factors affecting the distribution of debris flows in Nelson County, Virginia from Hurricane Camille (Gryta and Bartholomew, 1989) and of debris flows in Virginia and West Virginia in the storm of November 3-5, 1985 (Jacobson and others, 1993), bedrock lithology was found to be an important regional factor influencing debris-flow susceptibility. From studies in many areas worldwide, including the eastern Appalachians of Virginia (Hack and Goodlet, 1960), topographic concavities on steep hillsides, where colluvial soils accumulate and perched shallow ground water converges, favor debris-flow initiation (Reneau and Dietrich, 1987). Removal of vegetation by wildfire and timber harvesting can affect debris-flow susceptibility (Wells, 1987).

Potential debris-flow source areas can be identified on aerial photographs and from field mapping. Mapping topographic swales, together with categorizing slope steepness, has been used 
as an initial step in evaluating debris-flow hazards (fig. 10) (Smith, 1988). With the advent of computer-aided analyses of spatial data, digital elevation models from topographic data can be utilized to identify potential debris-flow source areas. Ellen and others (1993) identified potential debris-flow source, path, and depositional areas near Honolulu, Hawaii, using computer analyses of topographic data in conjunction with geologic studies of debris flows in the area.

Channels downslope from potential source areas of debris flows are extremely hazardous because debris flows move rapidly in steep channels. Debris flows can increase their volume by incorporating additional material from the bottom or sides of channels. Although residential development is not common within channels, transportation and lifeline routes, including roads, trails, and pipelines, must cross channels and are extremely vulnerable to debris flows. Culverts beneath roads that adequately transmit clear water streamflow are often of inadequate size for debris flows, which can block drainages and result in the subsequent failure of road embankments.

Once a debris flow emerges from a canyon, the problem of predicting its path across an alluvial fan becomes complicated by the ability of a flow to spread, to plug its channel, and to alter its course. The problem of forecasting the path and runout of debris flows can be addressed using several approaches: (1) historic or prehistoric distribution of debris-flow deposits, (2) empirical methods, and (3) mathematical models. Based on the distribution of mapped historic and prehistoric debris-flow deposits, Glancy and Katzer (1977) delineated different levels of debrisflow hazard for an area south of Reno, Nevada. Their evaluation predicted the general area impacted by a subsequent flow in 1983 , but failed to predict the extent of the affected area because the event occurred with a peak flow rate of water and debris that was much greater than anticipated (Glancy, 1985). Mapping the maximum limit of prehistoric debris-flow deposits provides an approximate boundary, but not the frequency or timing of debris flows. An investigation directed to dating of prehistoric deposits, such as by Lips and Wieczorek (1993), is required for assessments of the average recurrence interval of debris flows. Dating of prehistoric debris-flow deposits in the Davis Creek drainage basin of Nelson County, Virginia, approximately 90 miles south of Madison County, indicates that there have been at least three or four debrisflow events during the last $11,000 \mathrm{yr}$ in this one drainage basin; this would yield an average local return period of between 3000 and $4000 \mathrm{yr}$ (Kochel, 1987). These studies can at best provide minimum estimates.

Empirical methods of estimating debris-flow runout have been based on observations and relationships between runout and other parameters, such as the potential energy between the source area and head of the fan. As debris flows emerge from canyons onto fans, observations worldwide indicate that debris flows generally begin to deposit on gradients between $10 \%$ and 25\% and end at gradients of about 5\% (Ikeya, 1981; Mizuyama, 1981; and Daido, 1971). For debris flows in Utah, Vandre (1985) proposed that length of runout on a $10 \%$ or flatter gradient was proportional to the elevation difference between debris-flow source and the head of the fan. Whereas empirical methods may be useful for the area where they were developed, the unique geologic conditions make it difficult to transfer these methods to other regions without further calibration. 
Where debris-flow source areas have been delineated, hydrologic routing techniques can be used to estimate the path of a potential debris flow. The travel path or runout distance of a debris flow is affected by several factors, the most important of which are the rate of flow $\left(\mathrm{ft}^{3} / \mathrm{sec}\right)$, degree of slope of the channel and fan, and degree of confinement within the channel. Large, rapidly moving debris flows can surge (superelevate) around bends and overtop channels (fig. 11), occasionally entering an adjacent channel. Using an analytical model for volume-change behavior of debris flows, as proposed by Cannon and Savage (1988), Ellen and others (1993) used simulations of a standard-sized debris flow to track potential travel paths and map hazards from debris flows near Honolulu, Hawaii. This one-dimensional model best applies to flows on planar hillsides or in low-order drainages and is less accurate where flows emerge from a confining canyon and spread widely over alluvial fans.

More complex, two-dimensional mathematical models for debris-flow travel have been developed and calibrated based on individual events to determine flow depths, velocities, impact forces and areas of deposition (Mizuyama and others, 1987; Mizuyama and Ishikawa, 1990; O'Brien and Fullerton, 1990; Takahashi, 1991). Because mathematical methods require field measurements and consequently are calibrated for a specific site, the transferability of these methods to other areas needs to be tested. As a starting point, it is usually best to assume that the entire alluvial fan is at hazard unless it can be shown to be otherwise.

\section{HAZARD MITIGATION}

\section{Non-structural Methods}

Approaches to debris-flow hazard mitigation can be generally separated into those that involve construction of some type of physical structures or those that involve non-structural measures. The non-structural measures for debris-flow hazard mitigation are similar to some of those widely used for landslide hazard mitigation and can include removing or converting existing development, discouraging development, and regulating development (Erley and Kockelman, 1981). Non-structural measures can be especially cost effective if the areas in question are subject to frequent debris-flow events. Land-use regulations can be used to reduce hazards by limiting the type or amount of development in hazardous areas. A community can zone hazard-prone areas for open space uses like parks, grazing, or certain types of agriculture. Alternately, within high hazard zones, the intensity of development can be kept to a minimum. Zoning districts that are most compatible with landslide-hazard areas include agricultural, open-space, park, and recreation-use zones. In San Mateo County, California, for example, the board of supervisors created a resources management zoning district to carry out the objectives and polices of their open-space plan. Within these districts, regulations limit the number of dwellings in landslideprone areas to one unit per 40 acres. However, the number of dwellings permitted may be clustered in non-hazardous areas provided suitable sites can be located and the overall density of structures does not exceed the formula of 1 unit per 40 acres.

Monitoring, warning, and evacuation can also be considered as a non-structural approach to hazard mitigation. In order to increase the ability of emergency managers to respond to future potential events, an early warning system may be $\mathrm{d}$ 
(USGS), in cooperation with the U.S. National Weather Service (NWS), has developed a realtime warning system that was used to issue the first public regional warning for debris flows (and other landslides) in the United States during the storms of 12-21 February 1986 in the San Francisco Bay region. Debris flows and other landslides coincided with times of two separate warnings that were issued during the February 1986 storms (Keefer and others, 1987). These and subsequently issued warnings in the San Francisco Bay region were conveyed to local officials responsible for emergency services who deployed resources in areas likely to be affected. Based on the establishment of real-time rainfall monitoring systems by State and local agencies in many regions for flood forecasting purposes, the capability exists to develop similar landslide warning systems.

Automated detection and warning systems have been developed and employed in Alaska, Ecuador, and Philippines that can detect ground vibrations of passing debris flows, infer the relative magnitude of the flow, and transmit alarms to receivers downstream allowing time for evacuation of people and property. Seismic sensors placed next to channels have been used to detect and warn of approaching debris flows (LaHusen, 1990). Tripwire systems have also been employed to detect oncoming debris flows, but as with all these systems the channels must be well known and sufficiently long for the advance warning to be practically useful for rapidly moving debris flows.

\section{Structural Measures}

Different structural measures can be employed to lessen debris-flow hazards in source areas, channels, or on the fans (fig. 12). In debris-flow source areas, extensive grading to remove colluvial soils or other slope stabilization measures can reduce the debris-flow hazard associated with a particular soil-filled topographic depression; however, in most drainage basins there are many potential debris-flow source areas. Following numerous damaging debris flows and floods during the 1920's and 30's, the U.S. Forest Service successfully used contour trenches and revegetation on the damaged watersheds along the Wasatch Front, Utah, to minimize overland flow, erosion, and the generation of debris flows. The Uniform Building Code (UBC), published by the International Conference of Building Officials, is widely used as a local building code and also as a model for local grading regulations. The Los Angeles grading code, more detailed than the UBC provision, has effectively reduced landslide damage over several decades in southern California (Slosson and Krohn, 1979). Remediation of an individual landslide by excavation, installation of subdrains, or other site specific techniques can reduce the local likelihood of triggering debris flows, but is an expensive approach for mitigating debris-flow hazards in large regions.

Within channels and on fans, the most common method of entrapment of flowing debris is by check dams or by debris basins (figs. 13,14). Structures of this nature have a high initial cost and generally require annual or more frequent maintenance (fig. 15). In some applications, check dams within canyons are allowed to fill, which may also help stabilize the side slopes of channels. For debris basins surrounded by residential development, the capability to remove material may be necessary on a 24-hr basis during storms. These structures could be compatible with park and 
recreation areas. Check dams and debris basins have seen rather limited use in the United States, principally within heavily populated regions of southern California near Los Angeles and near Salt Lake City along the Wasatch Front in Utah; however, these methods have been extensively employed in Europe, Japan, China, and Indonesia.

A number of other structural measures have been applied to debris-flow problems. Debris fences on hillsides and in channels, typically consisting of a series of posts set in concrete and connected by wooden cross members or chain link fence (fig. 16), may retain the largest boulders and reduce the velocity of small flows, but may be ineffective with larger flows (Montgomery and others, 1991). Tree catchers are used to remove vegetation from flows within channels (fig. 17). Levees can be used to confine the transport of debris in channels, where debris basins are not practical until they reach locations where the debris can be ponded and deposited. Where debris basins are not practical, deflection walls can be used to direct debris flows around residences. Retaining walls can be designed to withstand and/or deflect impacts (fig. 18) (Hollingsworth and Kovacs, 1981; Baldwin and others, 1987), but walls may not be practical for large debris flows. Where debris flows enter residential areas, streets and drainage ditches can be utilized to convey the flows; residences along these conduits can be protected by sandbags, concrete block walls, and timber structures to block driveways (fig. 19).

\section{RECOMMENDATIONS}

The applicability of individual structural and non-structural measures to mitigate debrisflow hazards in the Blue Ridge Mountains of Virginia depends on the geographic extent, frequency, and magnitude of the debris-flow hazards as well as population density in this area. The following general recommendations to FEMA for initial steps toward hazard mitigation are suggested:

(1) Zoning ordinances in Madison and adjacent counties should be reviewed to determine if landuse restrictions related to slope instability and flooding exist that could be amended with the goal of reducing debris-flow hazards. During the period of rebuilding immediately following the recent disaster, adaptation and acceptance of new ordinances is potentially more likely. Although the present land use is primarily agricultural, new zoning regulations which address debris-flow hazards could be adopted to restrict residential hillside development. The existing land use may change within the next several decades as the Washington D.C./Fairfax/Manassas and Charlottsville communities expand into Madison County.

(2) The capability of establishing a real-time rainfall measurement system in Madison County and other counties along the Blue Ridge Mountains or anywhere where physiography in the Appalachians could produce a major orographic effect on rainfall should be examined. If no such system currently exists, the feasibility of establishing an automated telemetered rain gage system should be addressed with local agencies through the support and involvement of agencies including, but not limited to FEMA, National Weather Service (NWS), and Corps of Engineers. Such a system could be justified on the basis of providing emergency information necessary to operate a flood and landslide warning system for emergency responders and the public. A new 
continuous rainfall monitoring system could serve to both verify and supplement the recently employed NWS NEXRAD system that images clouds to estimate available moisture. The rainfall monitoring system should be coupled with an effective county system for warning people most vulnerable to debris flows and flooding.

(3) Because the debris flow episodes are widely spaced in time, people tend to forget about the hazard between events. An analysis of the 1995 storm examining debris flows including source areas, flow paths and consequences together with a range of potential responses to the threat could be helpful to people that are at risk throughout the Appalachians. A short pamphlet outlining the causes, locations, cosequences and responses could be helpful.

\section{REFERENCES}

Baldwin, J.E., II, Donley, H.F., and Howard, T.R., 1987, On debris flow/avalanche mitigation and control, San Francisco Bay area, California, in: Debris flows/avalanches: Process, recognition, and mitigation, Costa, J.E., and Wieczorek, G.F., eds., Geological Society of America, Reviews in Engineering Geology, V. 7, p. 223-236.

Campbell, R. H., 1975, Soil slips, debris flows, and rainstorms in the Santa Monica Mountains and vicinity, southern California, U.S. Geological Survey Professional Paper 851.

Cannon, S.H., and Ellen, S.D., 1985, Rainfall conditions for abundant debris avalanches, San Francisco Bay region, California, California Geology, v. 38, n. 12, p. 267-272.

Cannon, S. H., and Savage, W.Z., 1988, A mass change model for the estimation of debris flow runout, Journal of Geology, v. 96, p. 221-227.

Clark, G.M., 1987, Debris slide and debris flow historical events in the Appalachians south of the glacial border, in: Debris flows/avalanches: Process, recognition, and mitigation, Costa, J.E., and Wieczorek, G.F., eds., Geological Society of America, Reviews in Engineering Geology, V. 7, p. 125-138.

Daido. Atuyuki, 1971, On the occupance of mud-debris flow, Bulletin of Disaster Prevention, Kyoto University, v. 21, part 2, n. 187, p. 109-135.

Ellen, S.D., 1988, Description and mechanics of soil slip/debris flows in the storm, in Ellen, S.D., and Wieczorek, G.F., eds., Landslides, floods, and marine effects of the January 3-5, 1982, storm in the San Francisco Bay region, California: U.S. Geological Survey Professional Paper 1434, p. 63-112.

Ellen, S.D., Mark, R.K. Cannon, S.H., and Knifong, D.L., 1993, Map of debris-flow hazard in the Honolulu District of Oahu, Hawaii, U.S. Geological Survey Open-File Report 93-213. 
Erley, Duncan and Kockelman, W.J., 1981, Reducing landslide hazards: a guide for planers, American Planning Association, Planning Advisory Service Report Number 359, 29 p.

Glancy, P.A., 1985, The Ophir Creek debris flood of May 30, 1983--a real test of geohydrologic hazard mapping, Proceedings of a Specialty Conference on Delineation of Landslide, Flash Flood, and Debris Flow Hazards in Utah, Utah State University, p. 195.

Glancy, P.A., and Katzer, T.L., 1977, Flood and related debris flow hazards map, Washoe Lake area, Nevada, Environmental Series, Nevada Bureau of Mines and Geology.

Gryta, J.J., and Bartholomew, M.J., 1989, Factors influencing the distribution of debris avalanches associated with the 1969 Hurricane Camille in Nelson County, Virginia: in Schultz, A.P., and Jibson, R.W., eds., Landslide Processes of the eastern United States and Puerto Rico, Geological Society of America, Special Paper 236, p. 15-28.

Hack, J.T., and Goodlet, J.C., 1960, Geomorphology and forest ecology of a mountain region in the central Appalachians: U.S. Geological Survey Professional Paper 347, 66p.

Hollingsworth, R., and Kovacs, G.S., 1981, Soil slips and debris flows; Prediction and protection, Association of Engineering Geologists Bulletin, v. 18, n. 1, p. 17-28.

Ikeya, Hiroshi, 1981, A method of designation for area in danger of debris flows, Symposium on Erosion and sediment transport in Pacific Rim steeplands, New Zealand, International Association of Hydrological Sciences Publication No. 132, p. 576-588.

Jacobson, R.B., 1993, Introduction, in Geomorphic studies of the storm and flood of November 3-5, 1985, in the Upper Potomac and Cheat River basins in West Virginia and Virginia, Jacobson, R.B., ed., U.S. Geological Survey Bulletin 1981, p. A1-A3.

Jacobson, R.B., McGeehin, J.P., Cron, E.D., Carr, C.E., Harper, J.M., and Howard, A.D., 1993, Landslides triggered by the storm of November 3-5, 1985, Wills Mountain anticline, West Virginia and Virginia, in Geomorphic studies of the storm and flood of November 3-5, 1985, in the Upper Potomac and Cheat River basins in West Virginia and Virginia, Jacobson, R.B., ed., U.S. Geological Survey Bulletin 1981, p. C1-C33.

Jibson, R.W., 1989, Debris flows in southern Puerto Rico, in: Landslide processes of the eastern United States and Puerto Rico, Schultz, A.P., and Jibson, R.W., eds., Geological Society of America, Special Paper 236, p. 29-56.

Keefer, D.K., Wilson, R.C., Mark, R.K., Brabb, E.E., Brown, W.M. III, Ellen, S.D., Harp, E.L., Wieczorek, G.F., Alger, C.S., and Zatkin, R.S., 1987, Real-time landslide warning during heavy rainfall: Science, v. 238, p. 921-925. 
Koch, C.A., 1974, Debris slides and related flood effects in the 4-5 August 1938 Webb Mountain cloudburst; Some past and present environmental geomorphic implications, M.S. Thesis, Knoxville, University of Tennessee, 112p.

Kochel, C.R., 1987, Holocene debris flows in central Virginia, in: Debris flows/avalanches: Process, recognition, and mitigation, Costa, J.E., and Wieczorek, G.F., eds., Geological Society of America, Reviews in Engineering Geology, V. 7, p. 139-155.

LaHusen, R.G., 1990, Debris-flow detection system, in: The eruption of Redoubt Volcano, Alaska, December 14, 1989-August 31, 1990, U.S. Geological Survey Circular 1061.

Lips, E.W., and Wieczorek, G.F., 1990, Recurrence of debris flows on an alluvial fan in Central Utah: American Society of Civil Engineers, Proceedings of International Symposium Hydraulics/Hydrology of Arid Lands, San Diego, California, July 30- August 2, 1990, p. 555-560.

Mizuyama, Takahisa, 1981, An intermediate phenomenon between debris flow and bed load transport, Symposium on erosion and sediment transport in Pacific Rim steeplands, New Zealand, International Association of Hydrological Sciences, Publication No. 132, p. 211221.

Mizuyama, T., and Ishikawa, Y., 1990, Prediction of debris flow prone areas and damage, American Society of Civil Engineers, Proceedings of International Symposium Hydraulics/Hydrology of Arid Lands, San Diego, Calif., p. 712-717,

Mizuyama, T., Yazawa, A., and Ido, K., 1987, Computer simulation of debris flow depositional processes, International Association of Hydrological Sciences, Publication No. 165, p. 179-190.

Montgomery, D.R., Wright, R.H., and Booth, T., 1991, Debris flow hazard mitigation for colluvium-filled swales, Bulletin of the Association of Engineering Geologists, v. 28, n. 3, p. 303-323.

Neary, D.G., and Swift, L.W., Jr., 1987, Rainfall thresholds for triggering a debris-flow avalanching event in the southern Appalachian Mountains, in: Debris flows/avalanches: Process, recognition, and mitigation, Costa, J.E., and Wieczorek, G.F., eds., Geological Society of America, Reviews in Engineering Geology, V. 7, p. 81-92.

O'Brien, J.S., and Fullerton, W.T., 1990, Two-dimensional modeling of alluvial fan flows, American Society of Civil Engineers, Proceedings of International Symposium Hydraulics/Hydrology of Arid Lands, San Diego, Calif., p. 263-273. 
Pierson, T.C., and Costa, J.E., 1987, A rheologic classification of subaerial sediment-water flows, in: Debris flows/avalanches: Process, recognition, and mitigation, Costa, J.E., and Wieczorek, G.F., eds., Geological Society of America, Reviews in Engineering Geology, V. 7, p. 1-12.

Reneau, S.L., and Dietrich, W.E., 1987, The importance of hollows in debris flow studies; examples from Marin County, California, in: Costa, J.E., and Wieczorek, G.F., eds., Debris flows/avalanches: Process, recognition, and mitigation, Geological Society of America, Reviews in Engineering Geology, V. 7, p. 165-180.

Slosson, J.E., and Krohn, J.P., 1979, AEG building code review-Mudflow/debris flow damage; February 1978 storm, Los Angeles area: California Geology, v. 32, n. 1, p. 8-11.

Smith, T.C., 1988, A method for mapping relative susceptibility to debris flows, with an example from San Mateo County, in Ellen, S.D., and Wieczorek, G.F., eds., Landslides, floods, and marine effects of the January 3-5, 1982, storm in the San Francisco Bay region, California: U.S. Geological Survey Professional Paper 1434, p. 185-194.

Takahashi, Tamotsu, 1991, Debris Flow, A.A. Balkema, Rotterdam, 165p.

Vandre, B.C., 1985, Rudd Creek debris flow, Proceedings of a Specialty Conference on Delineation of Landslide, Flash Flood, and Debris Flow Hazards in Utah, Utah State University, p. 117-131.

Varnes, D.J., 1978. Slope movement types and processes, In Landslides Analysis and Control. in: R.L. Schuster and R.J. Krizek, eds., Transportation Research Board, Special Report 176, National Academy of Science, Washington, D.C., p. 12-33.

Weber, F.H., Jr., 1980, Landsliding and flooding in southern California during the winter of 197980: California Division of Mines and Geology Open-File Report 80-3 LA, 69 p.

Weber, F.H., Jr., Treiman, J.A., Tan, S.S., and Miller, R.V., 1979, Landslides in the Los Angeles region, California. Effects of February-March 1978 rains: California Division of Mines and Geology Open-File Report OFR 794 LA, Preliminary Edition, 265 p.

Wells, W.G. II, 1987, The effects of fire on the generation of debris flows in southern California: in: Costa, J.E., and Wieczorek, G.F., eds., Debris flows/avalanches: Process, recognition, and mitigation, Geological Society of America, Reviews in Engineering Geology, V. 7, p. 105-114.

Wieczorek, G.F., Lips, E.W., and Ellen, S.D., 1989, Debris flows and hyperconcentrated floods along the Wasatch Front, Utah, 1983 and 1984: Association of Engineering Geologists Bulletin, v. 26, no. 2, p. 191-208. 
Williams, G.P., and Guy, H.P., 1973, Erosional and depositional aspects of Hurricane Camille in Virginia: U.S. Geological Survey Professional Paper 804, 80 p.

Wilson, R.C., Torikai, J.D., and Ellen, S.D., 1992, Development of rainfall warning thresholds for debris flows in the Honolulu District, Oahu, U.S. Geological Survey Open-File Report 92521. 


\section{GLOSSARY}

ALLUVIAL FAN (FAN)-a generally planar surface in a larger valley downslope from the mouth of a canyon. The fan consists of materials deposited by flooding and debris flows.

CHECK DAMS-concrete or masonry structures in canyons designed to retain debris flows and to stabilize channels. Deposits in check dams are not normally removed.

COLLUVIUM- a general term applying to loose and incoherent deposits, usually at the foot of a slope brought there chiefly by gravity.

CONCAVITY -a topographic depression on a hillside, also referred to as a "hollow" or swale. The concavity is usually both across the slope horizontally and along a vertical profile. A concave hillside is contrasted with a flat or planar hillside and with a convex hillside, both in plan and in profile.

DEBRIS BASIN-an earthen or concrete structure designed to retain debris flows, often equipped with spillways to pass more fluid portions of flow and slotted towers to drain water from deposits. Debris basins require maintenance; deposits must be removed to maintain storage capacity for future events.

DEBRIS FLOW- a form of rapid mass movement of granular solids, water, and vegetation with flow properties that vary with water content, sediment size, and sorting of particles.

HEAD OF A FAN-the apex or upslope point where an alluvial fan intersects a channel emerging from a canyon.

LANDSLIDE-a broad term encompassing a wide variety of types of slope movement including the main categories of movement--slides, falls, topples, spreads and flows.

PERCHED WATER TABLE-the level of water in a hillside over an impermeable, non-saturated zone. Temporary perched water tables are generally created during storms with high intensity rainfall within shallow soils over less permeable bedrock.

SOIL SLIP-a common term used to describe a type of slope movement involving shallow sliding within a layer of soil. If sufficient moisture exists within or is added to the soil, these soil slips can mobilize into debris flows.

SOURCE AREA-the hillside area where landslides are triggered and debris flows are initiated. Most frequently topographic swales on hillsides that are filled with colluvial soils are the source area for debris flows.

SLURRY-for debris flows indicates a fluid-like mixture of different sized particles, from clay- to 
boulder-sized mixed with water.

VISCOUS-a descriptive term meaning fluid-like; in the case of debris flows, sediment and boulders added to water increase the amount of viscosity. 


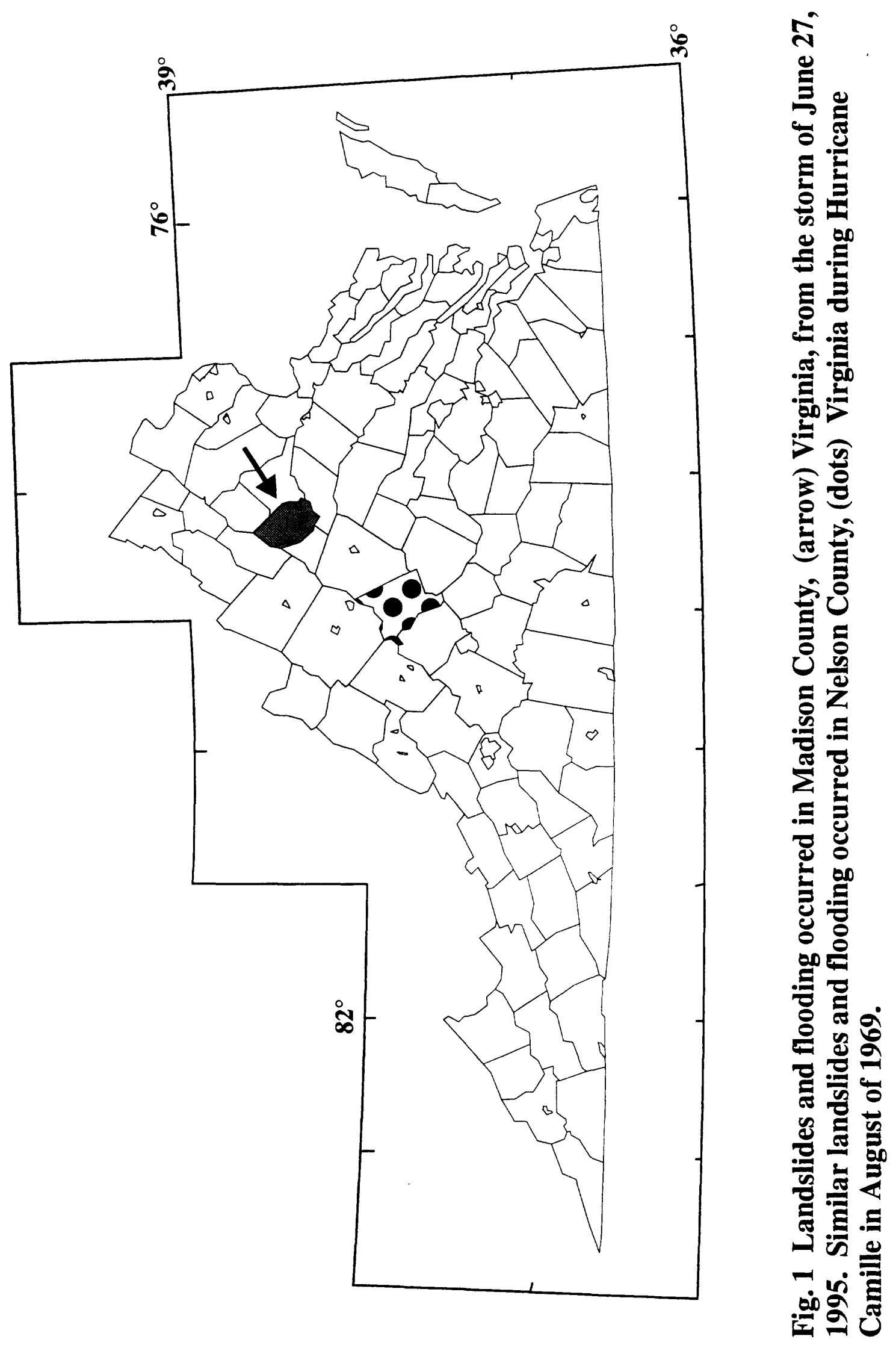




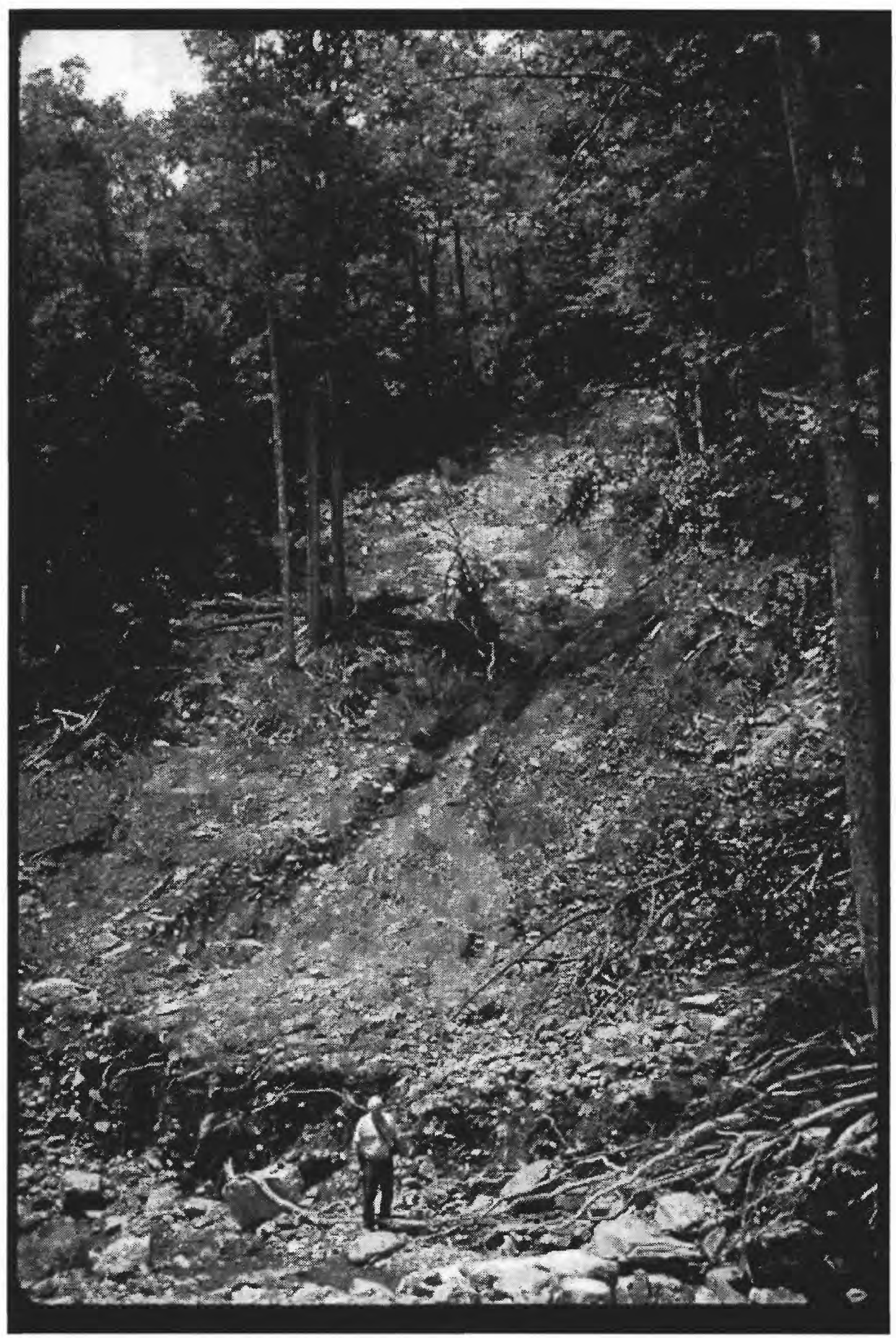

Fig. 2- Shallow soil slide and debris flow that stripped vegetation from hillside during the storm of June 27, 1995, in Madison County. Debris flow entered channel (at location of person) adding sediment to stream. 


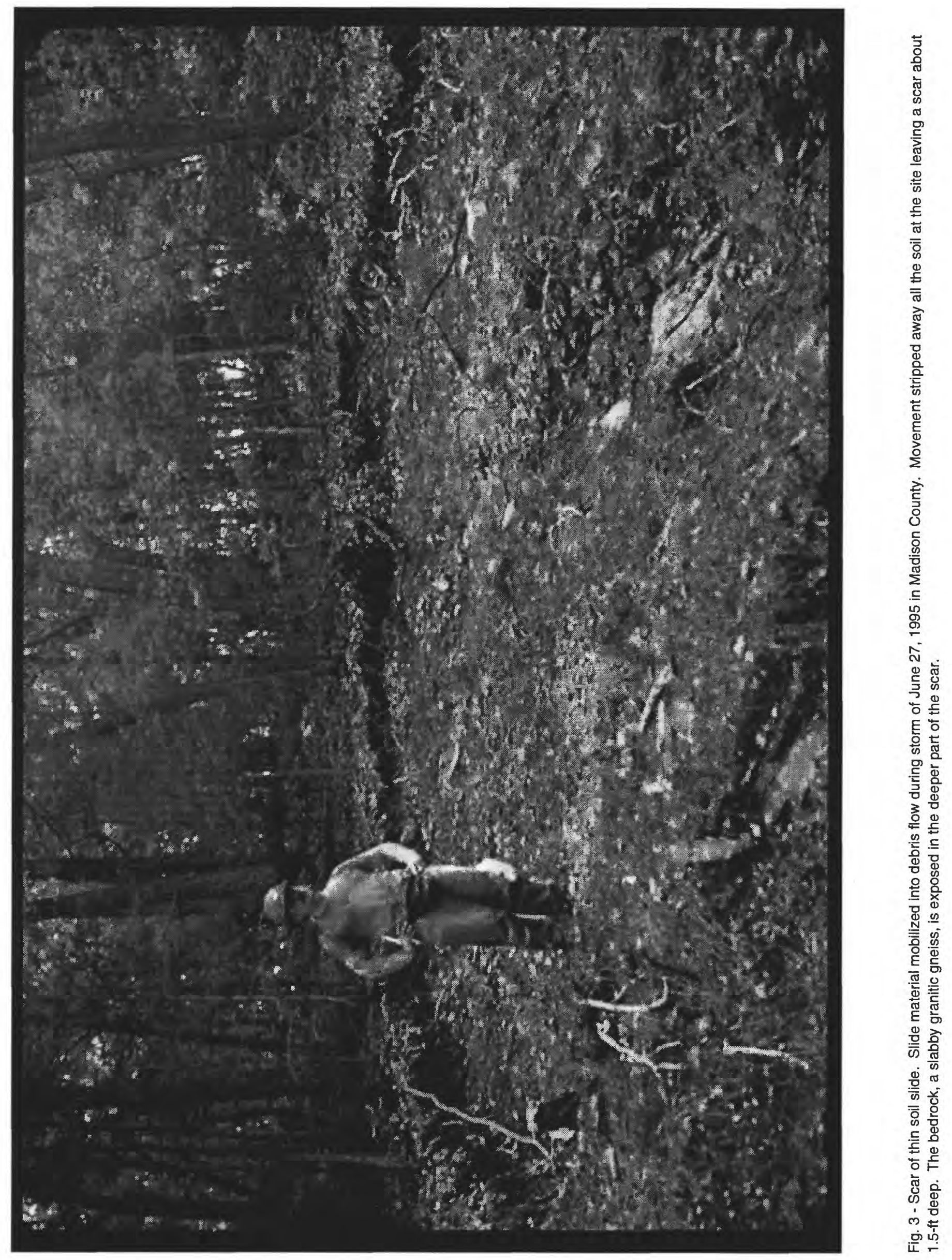




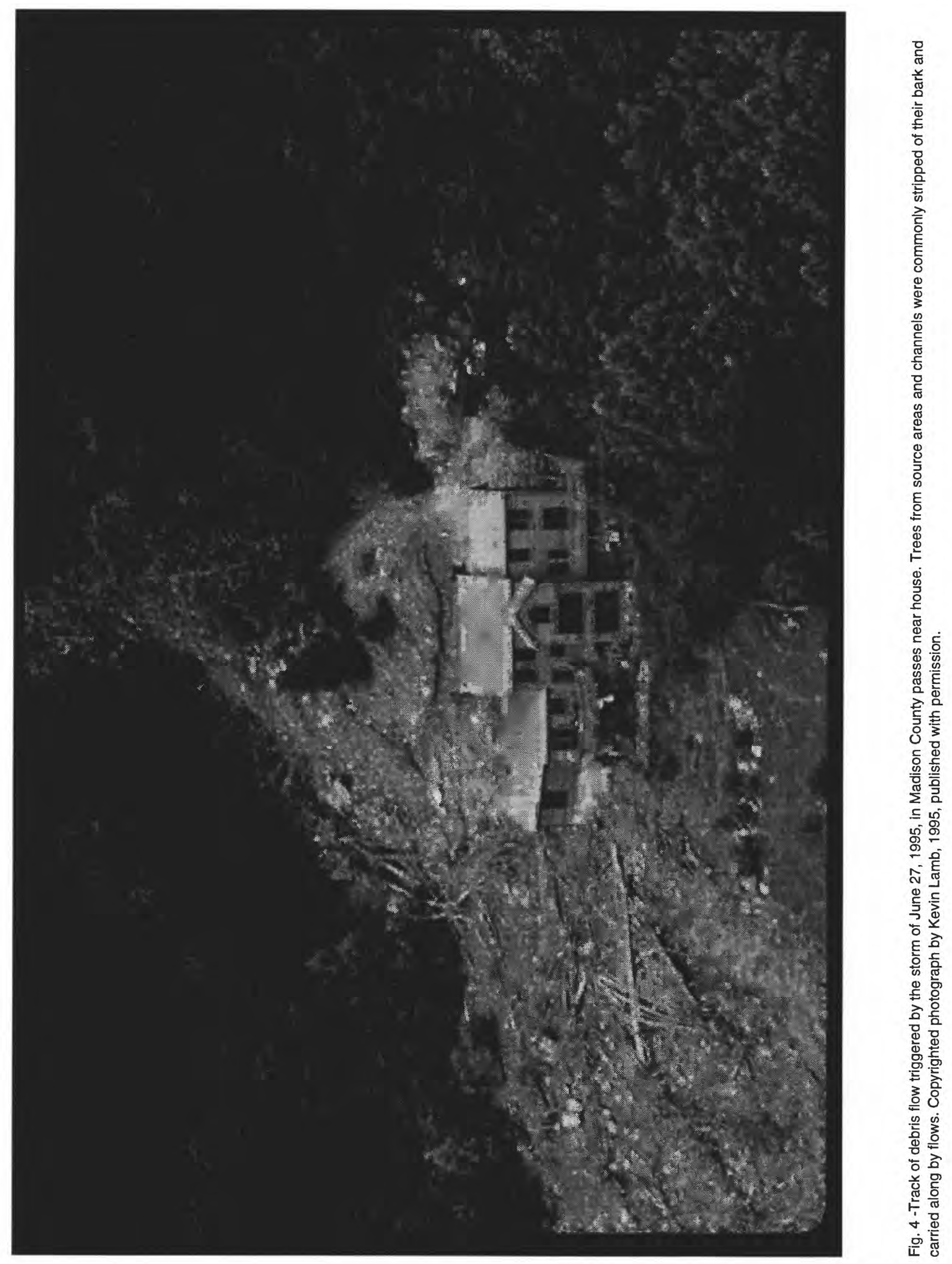




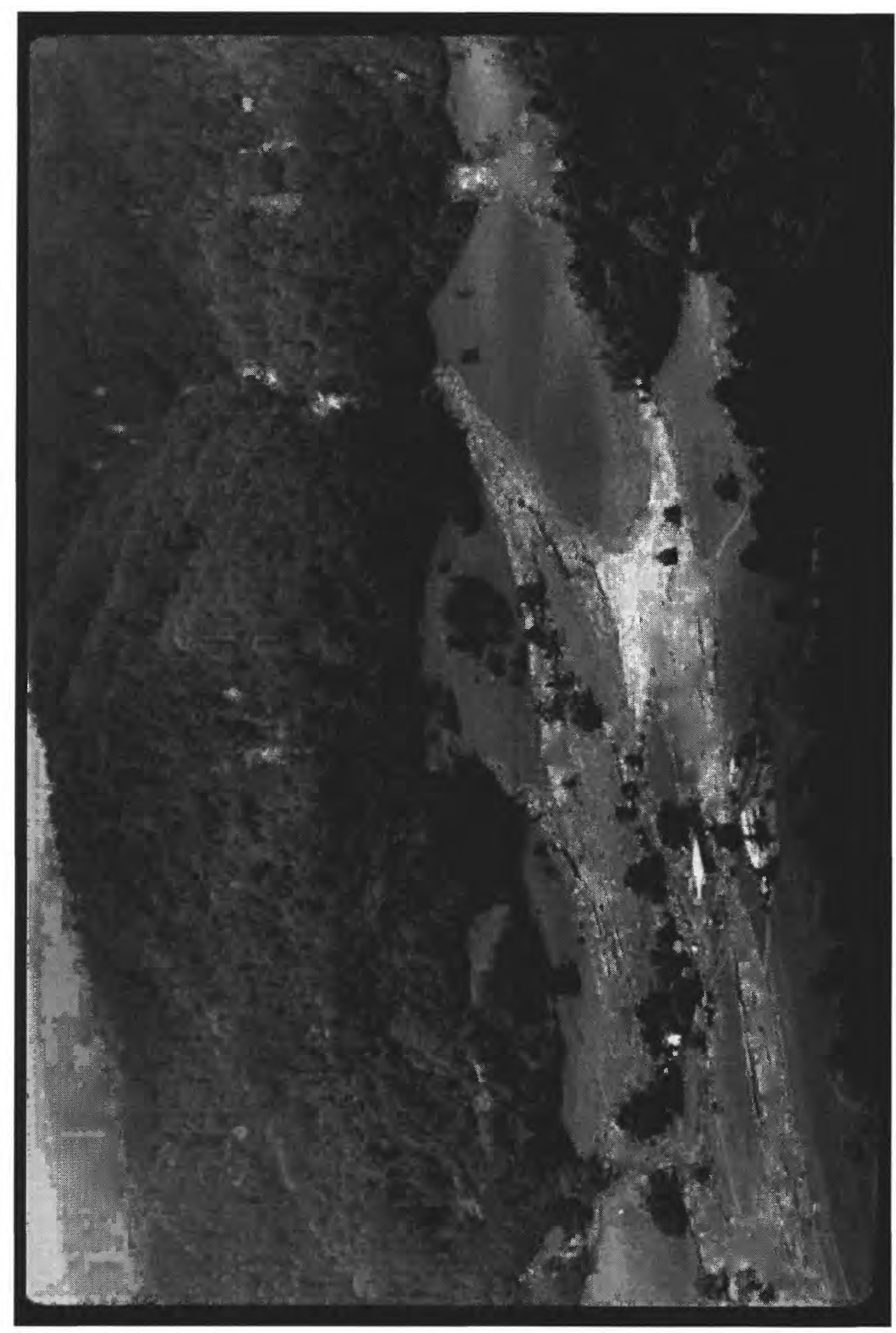

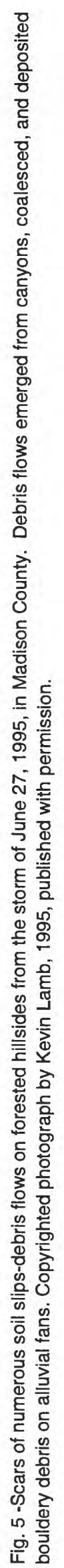




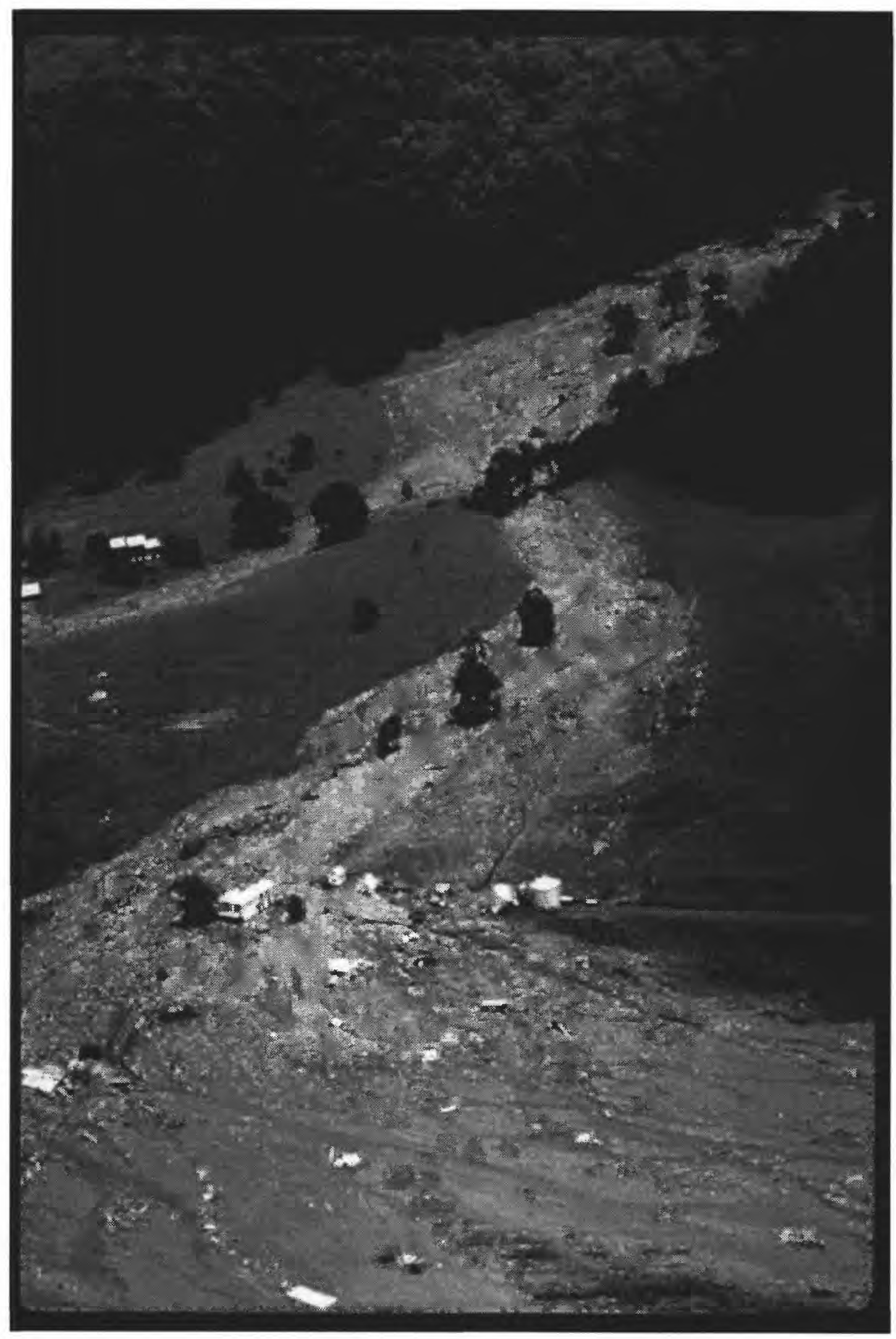

Fig. 6 -A debris flow emerged from a cariyon (upper right) and spread over an alluvial fan depositing bouldery debris during the storm of June 27, 1995, in Madison County. The impact from debris flows displaced and destroyed several structures on this farm near Graves Mill. Copyrighted photograph by Kevin Lamb, 1995, published with permission. 


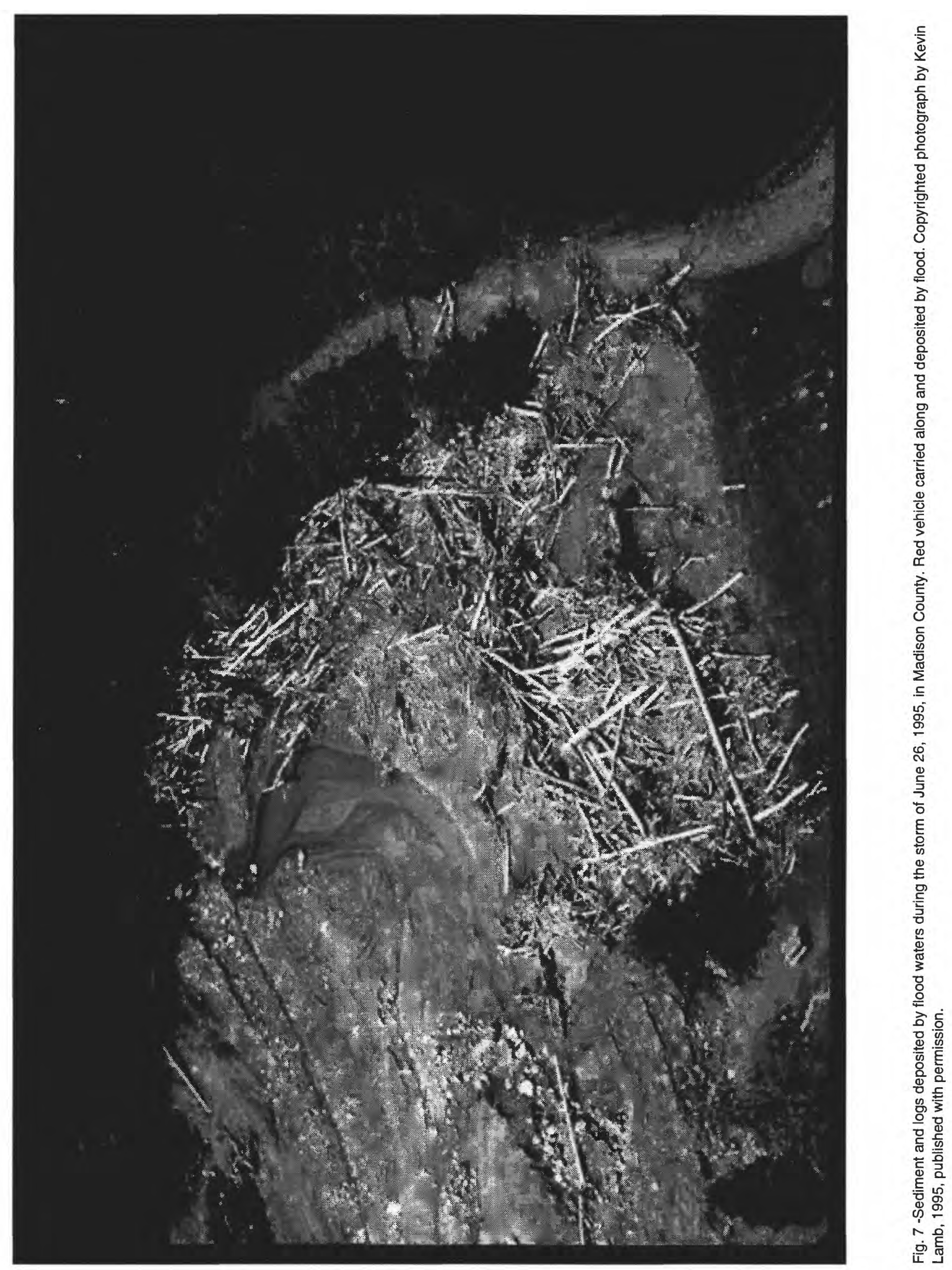




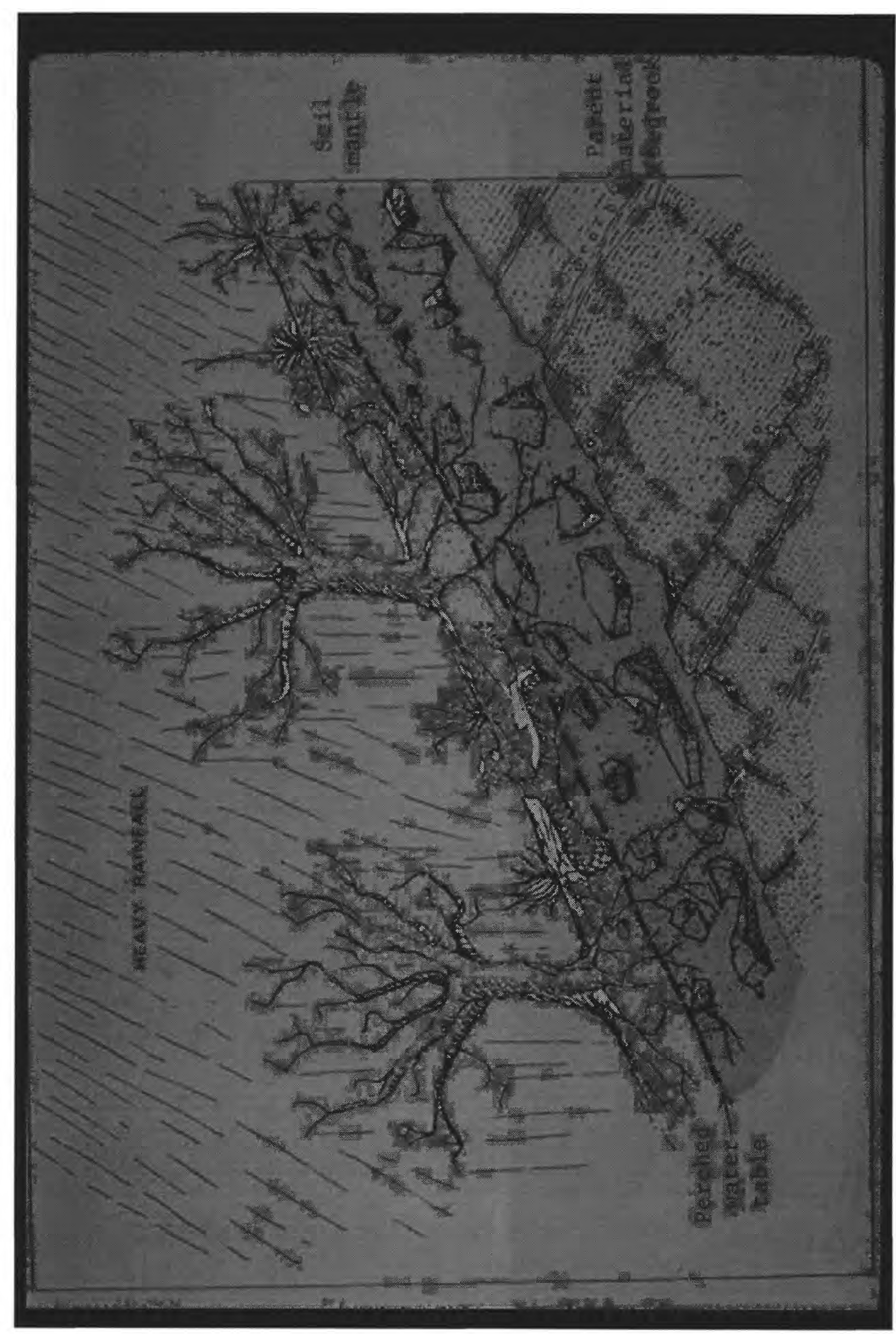

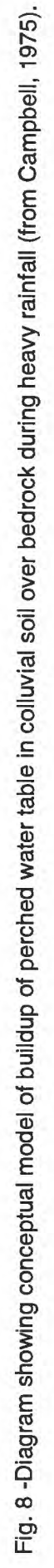




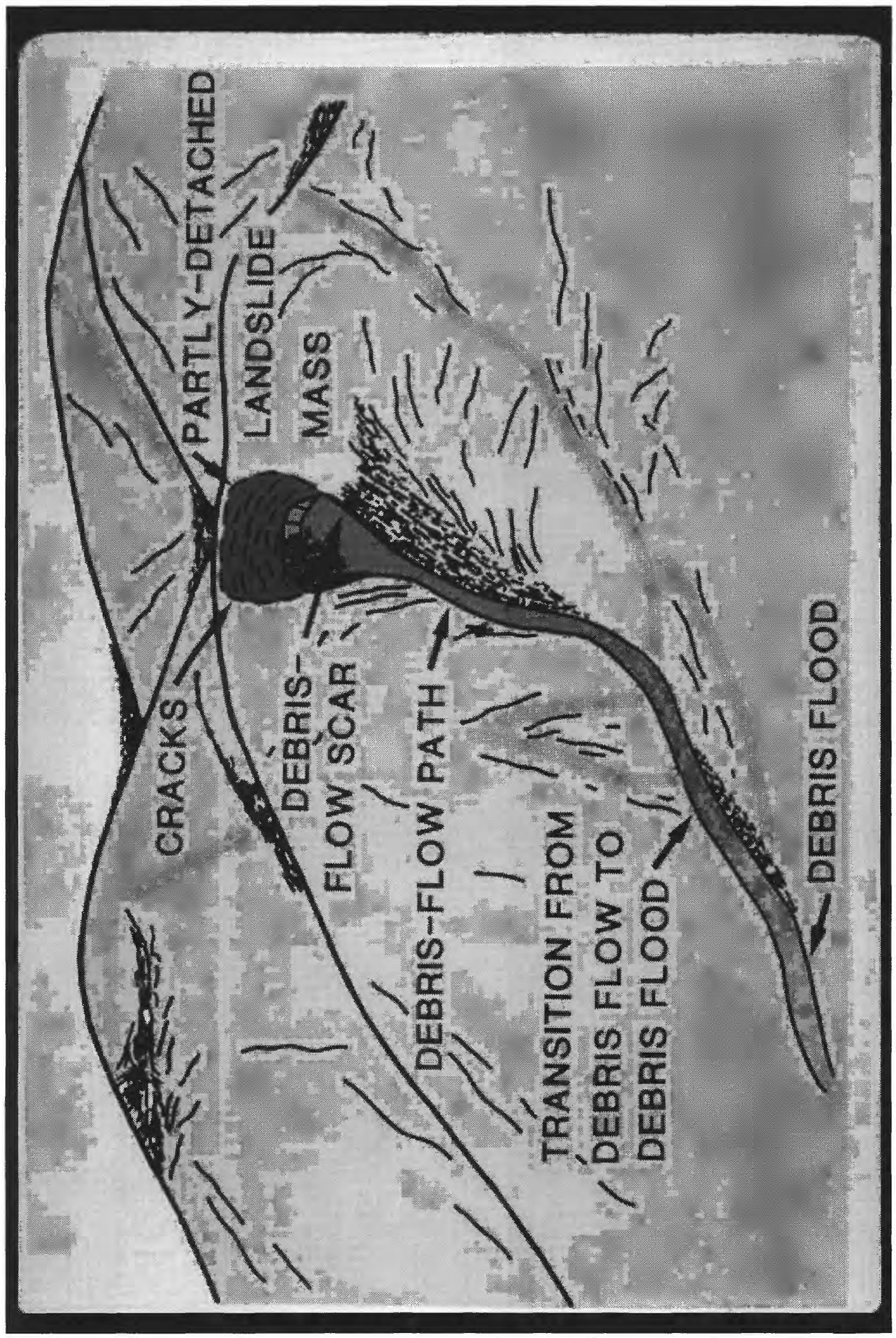

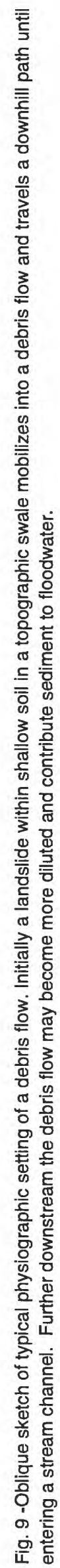




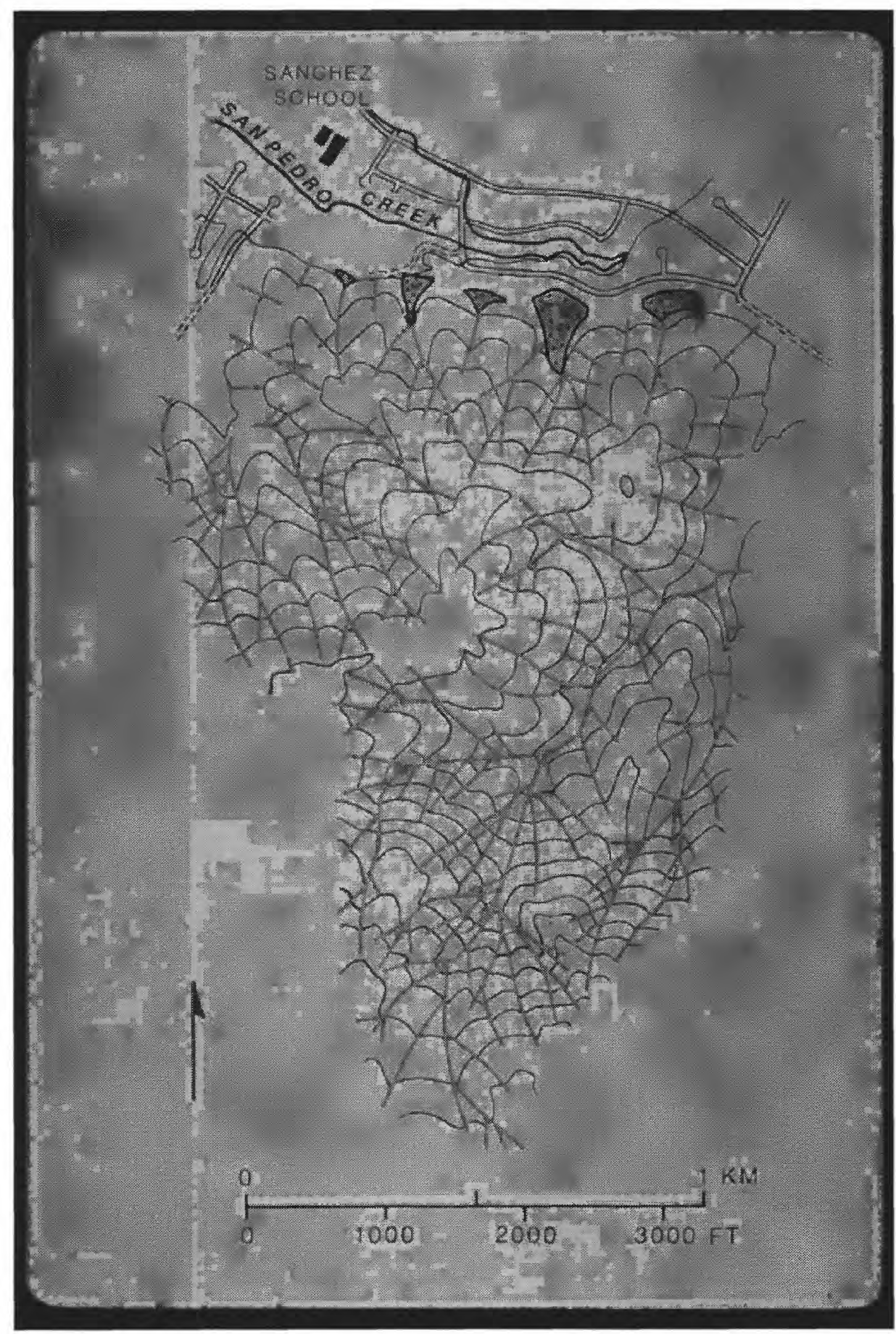

Fig. 10 -Map showing a pattern of natural drainages and alluvial fans. These drainages and fans are the most likely paths for debris flows to travel and deposit. Modified from Smith (1988). 


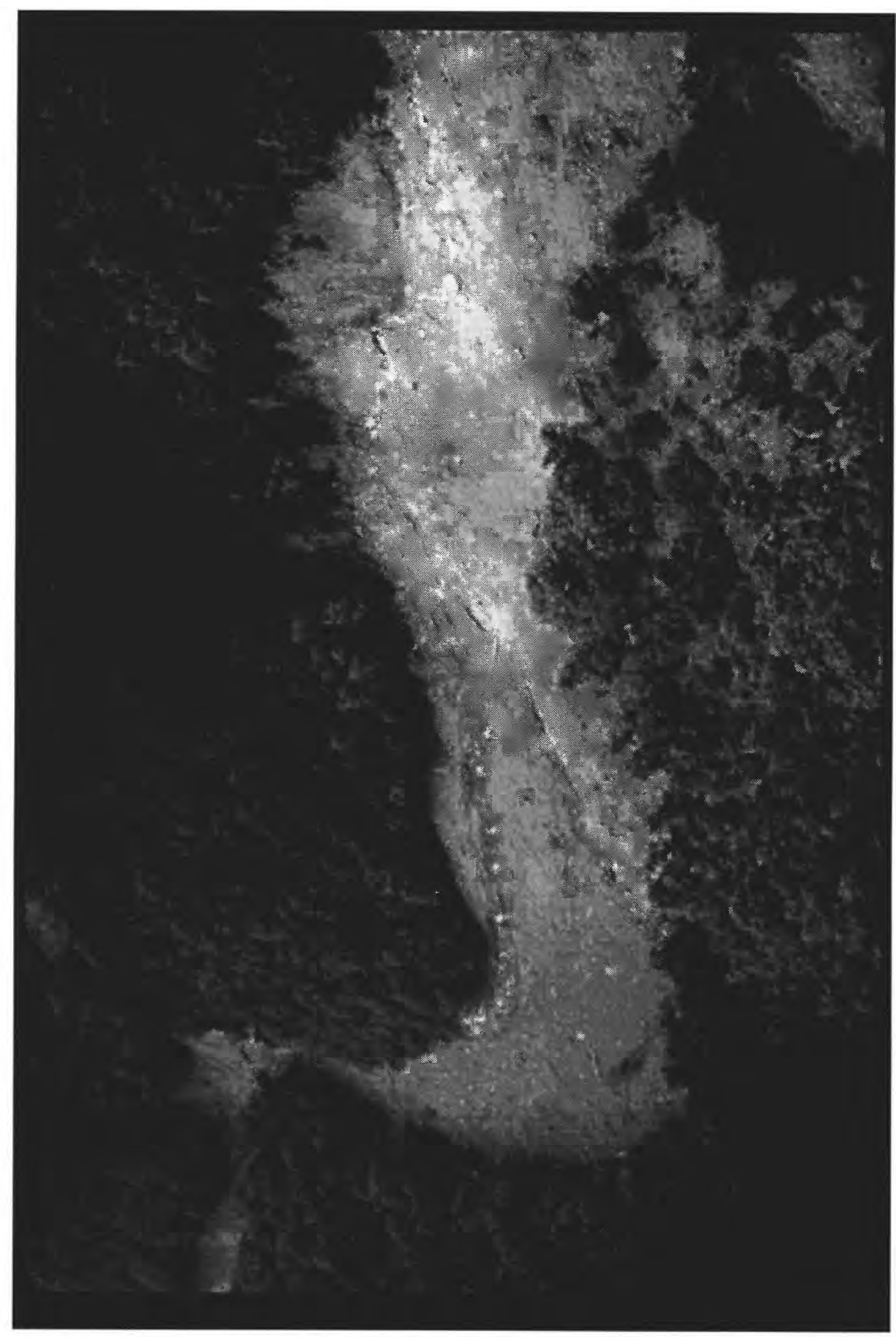

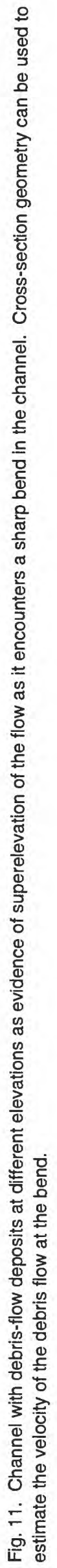




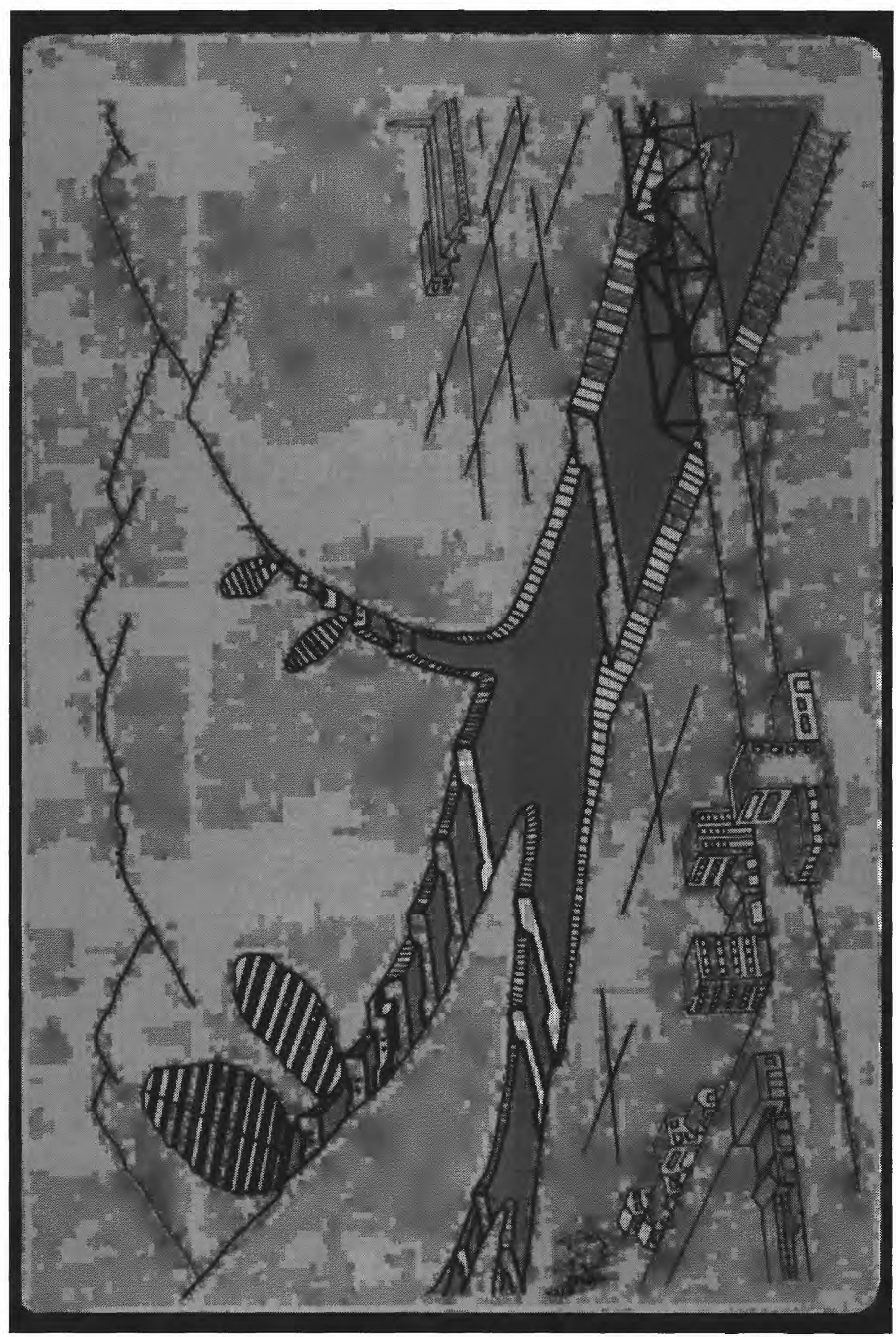

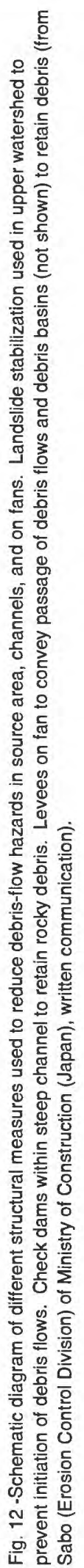




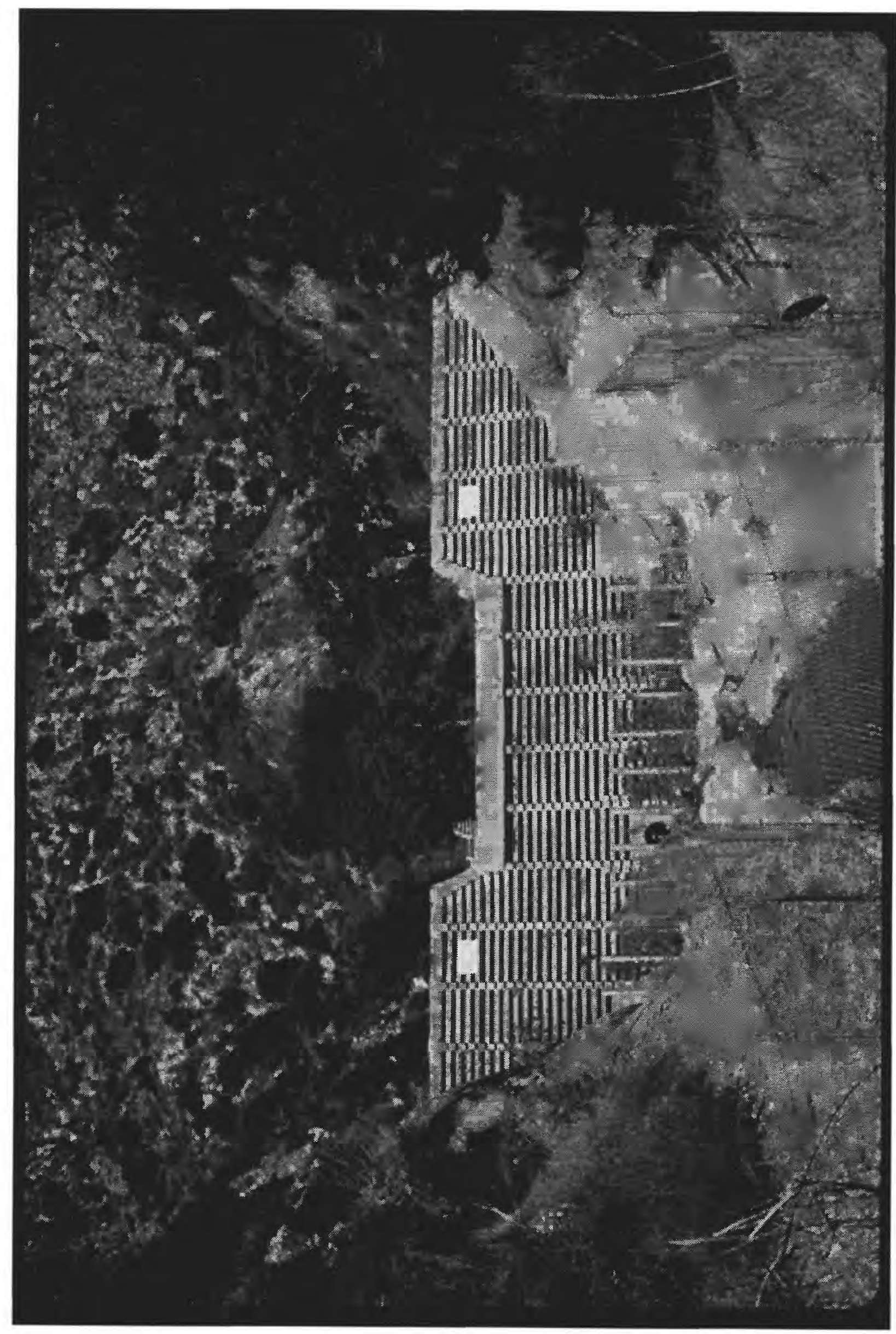

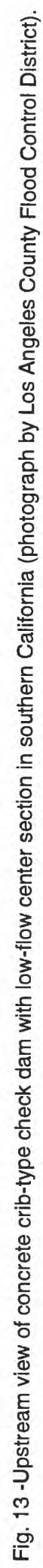




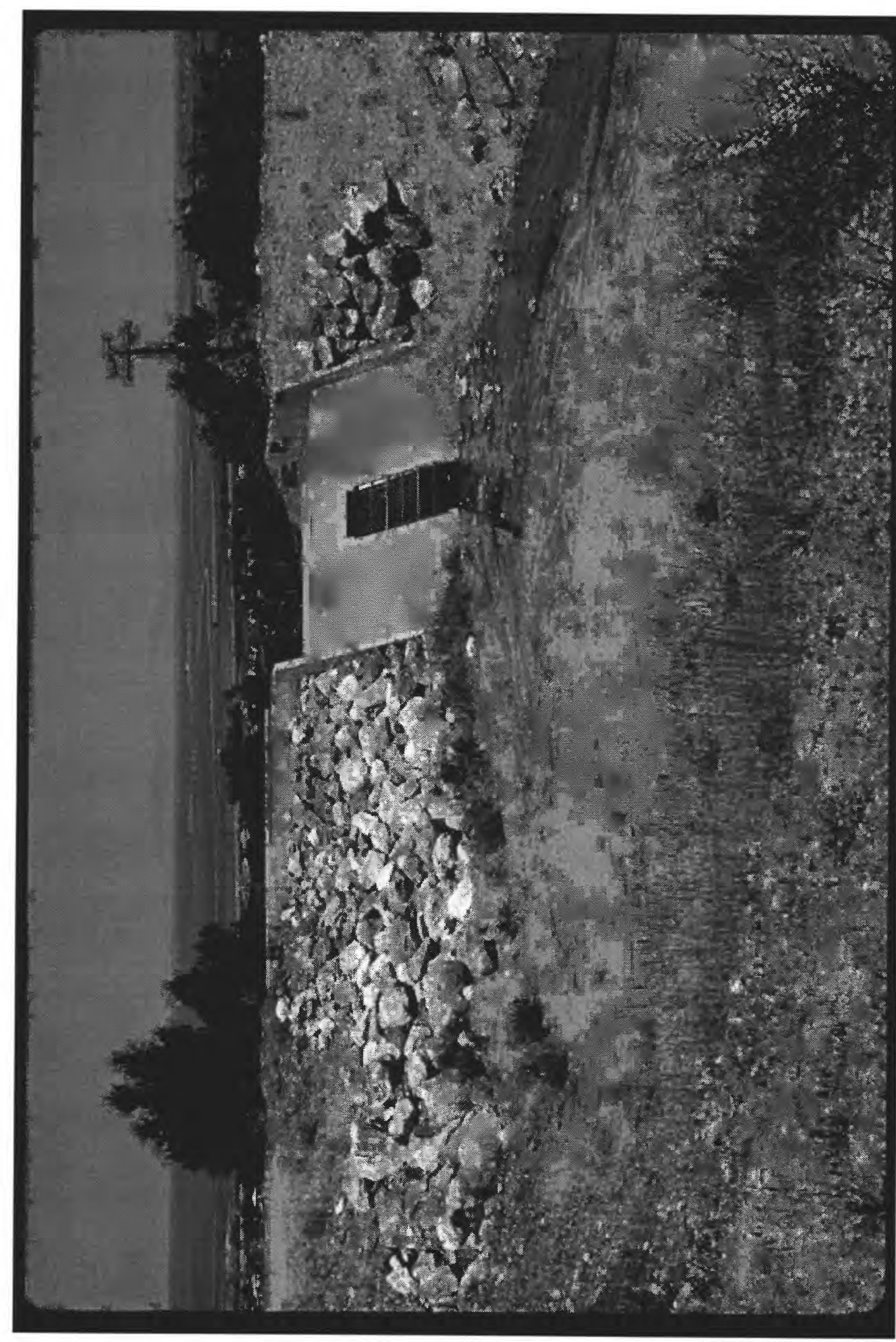

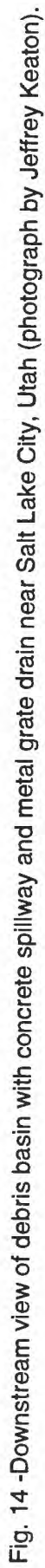




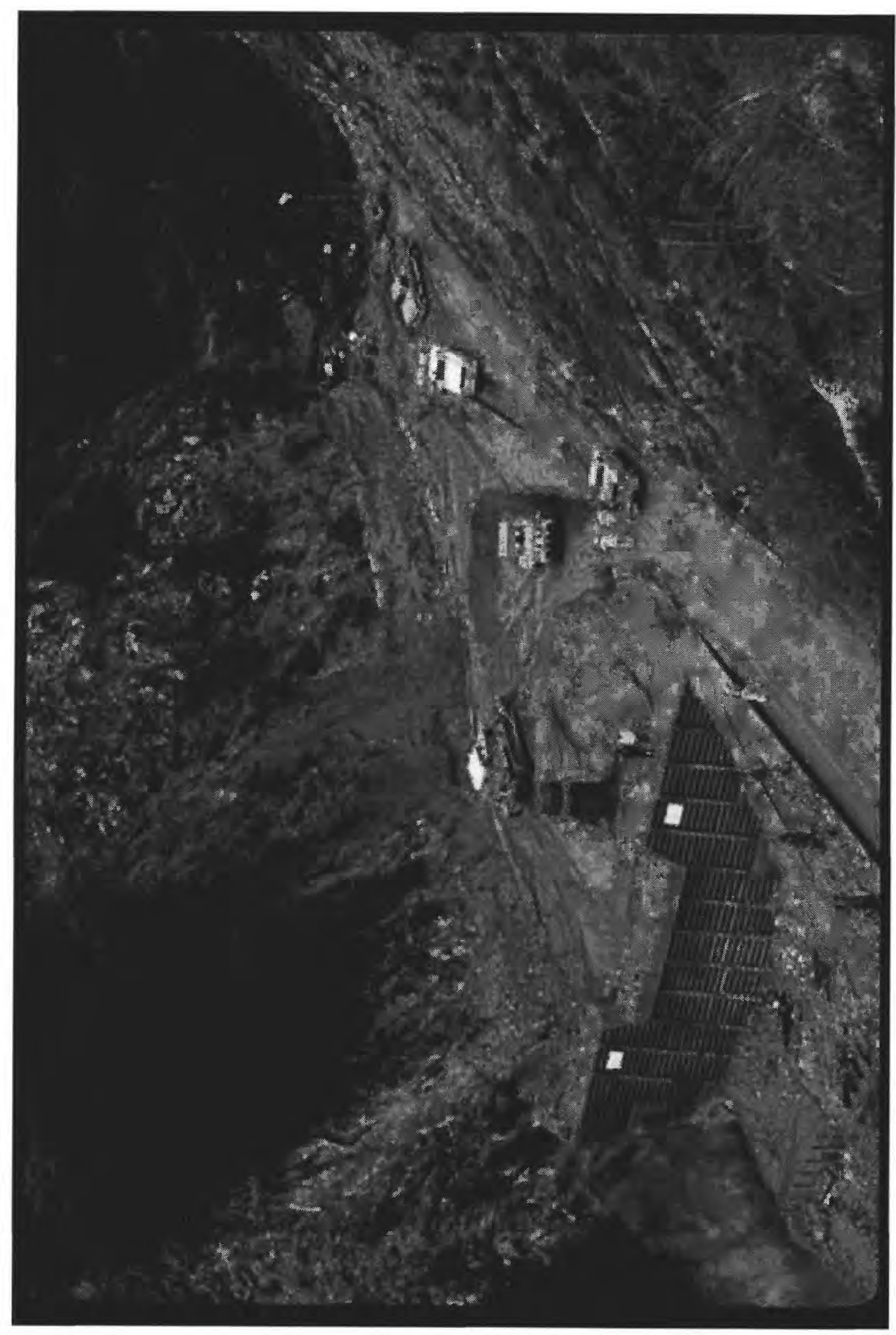

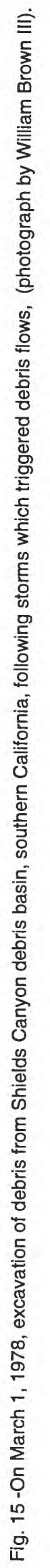




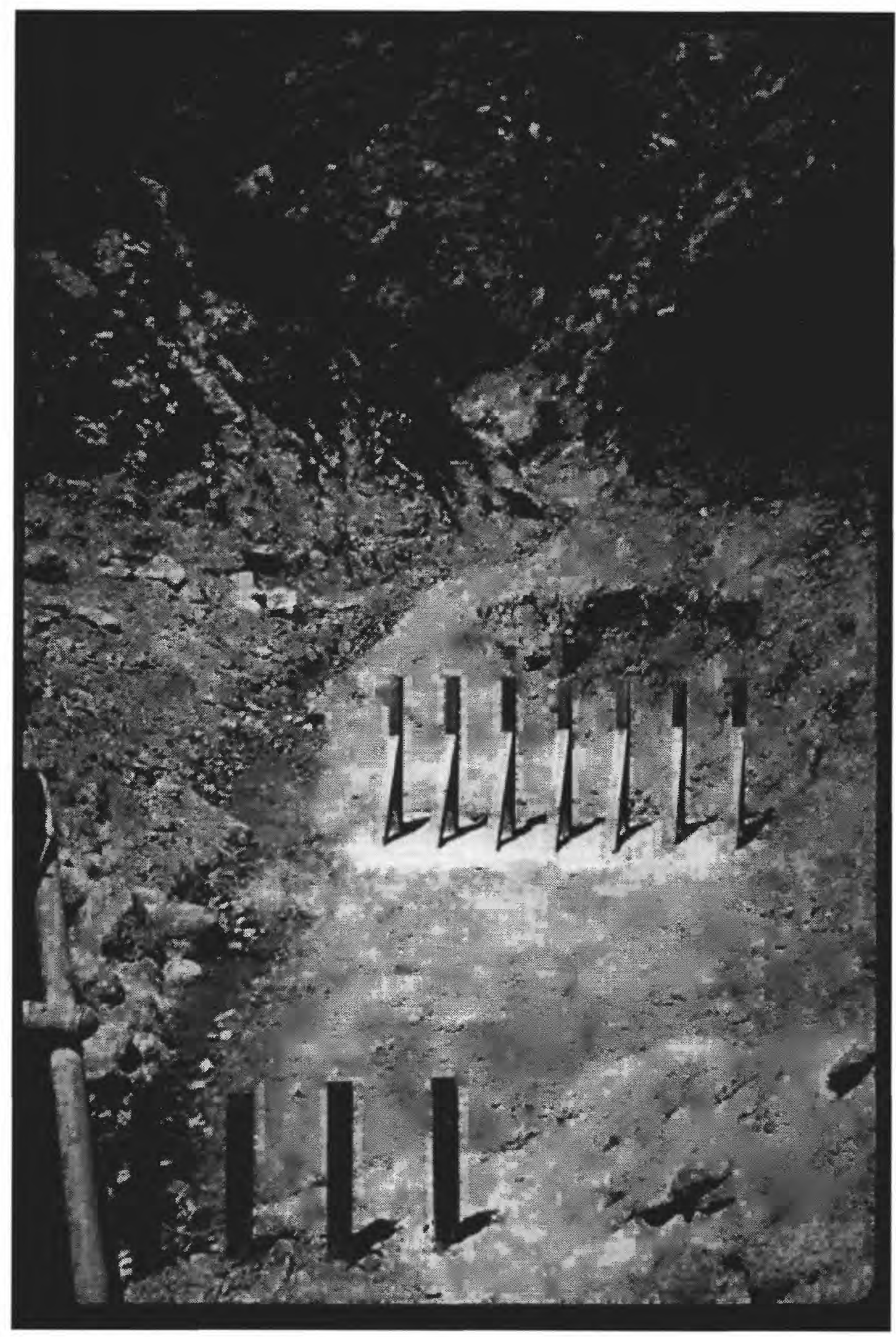

Fig. 16 -Debris fences to retain coarser debris and allow more fluid portion of flows to pass in channel in southern California. By removing large pieces of vegetation and coarser debris, downstream culverts and channels are prevented from clogging. 


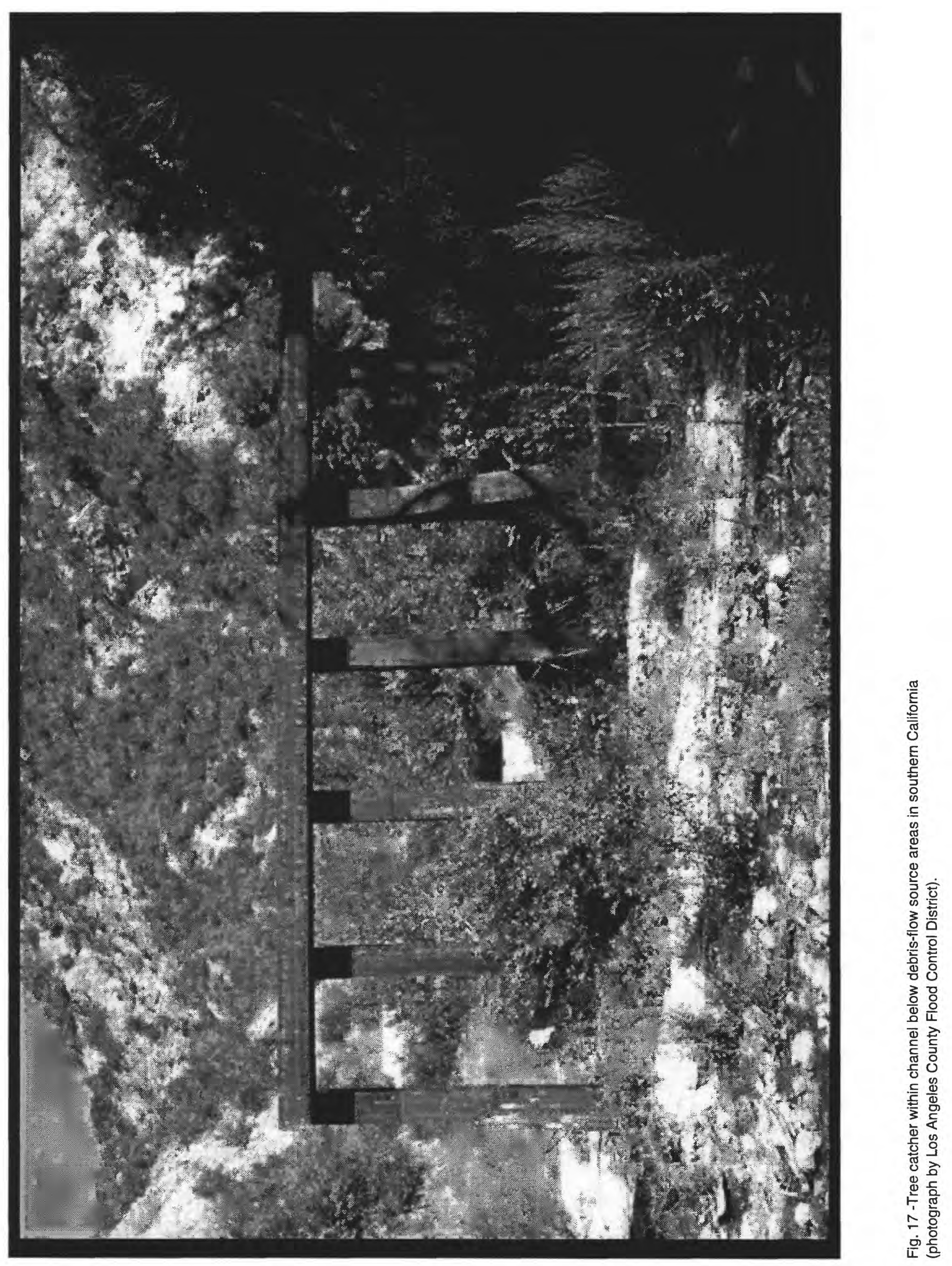




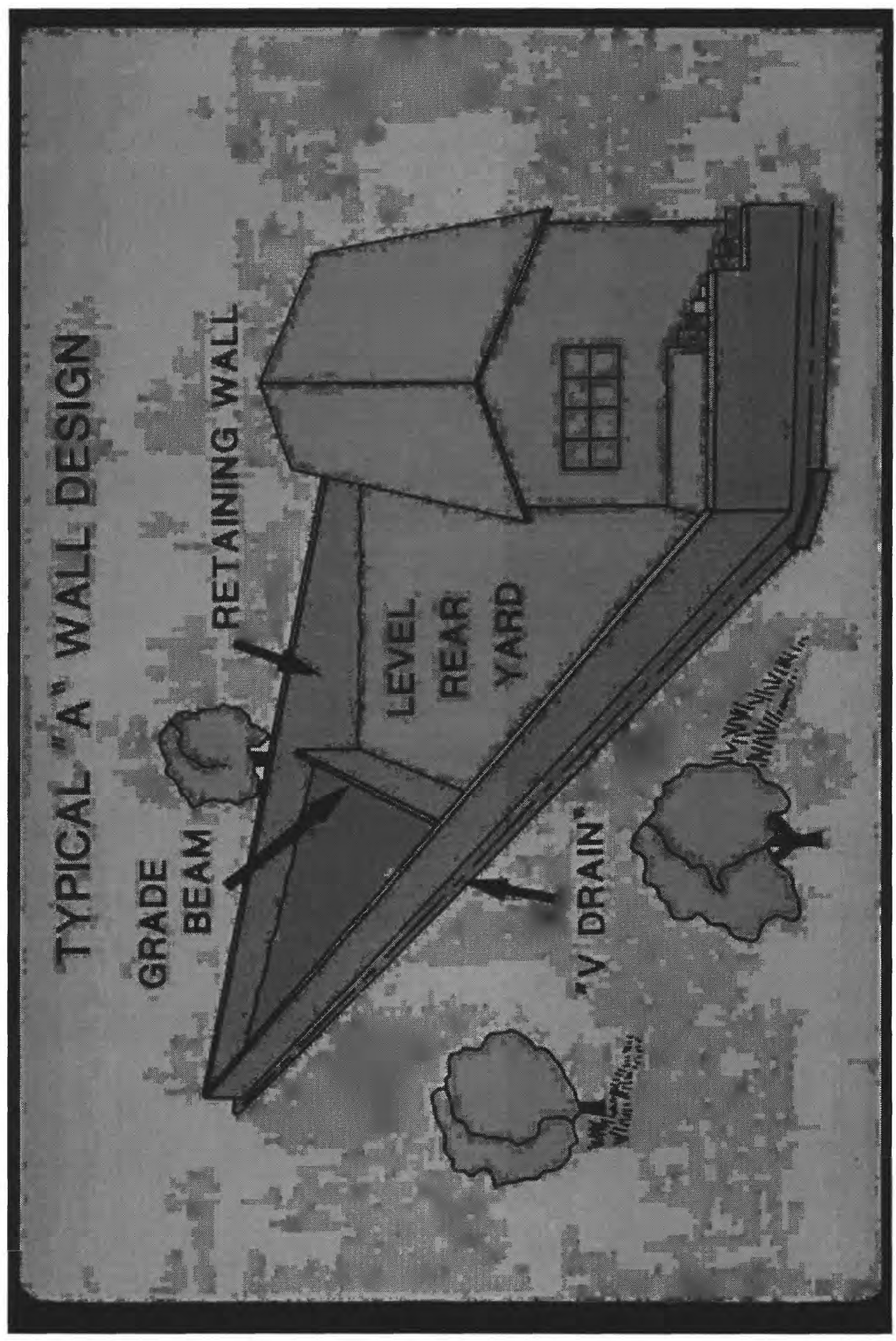

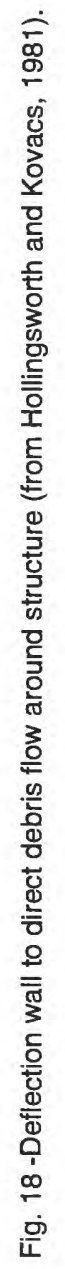




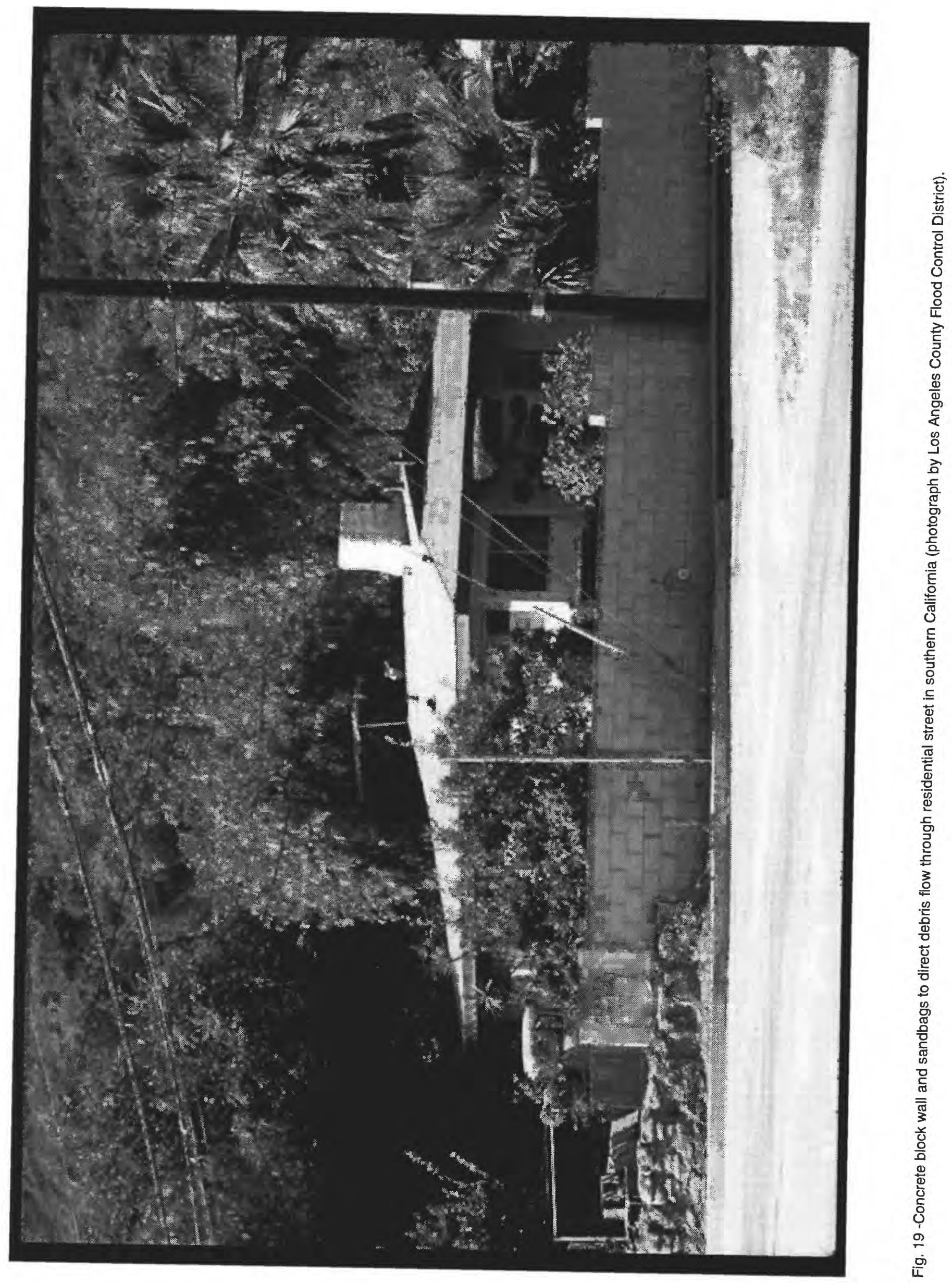

